\title{
CHURCH AND POLITICAL SOCIETY
}

\author{
PhD. Marin BUGIULESCU, \\ Professor, Director of "Saint John Chrysostom" Orthodox Theological Seminary, Târgovişte, \\ Member of Dumitru Stăniloae Scientific and Interdisciplinary \\ Research Centre, Valahia University, Târgoviște, \\ ROMANIA, \\ Email: m_bugiulescu@yahoo.com
}

\begin{abstract}
The Church and the Society are two unquestionable, undeniable realities that intertwine in countless ways. Every society assumes the idea of community, and the whole human society is the entirety of all human communities. Universal ideals are being invoked through universal systems. What ideology exists within today's societies in the world? It is Secularization. This is the ideology that some philosophers call liberalism. Initially the reform was followed by the era of the Enlightenment. The basis of this philosophy is the idea of personality, human rights and liberty. The man has become a measure of all things and he thinks he is in power to say: I decide what I need and not God at all. These ideas are closely related to the ones of the Renaissance - the rebirth of paganism, the atheistic vision of the world. All the Olympians were gods. This is the sinful man who instituted and developed the idea of rights and freedom, bypassing the idea of moral responsibility before God.
\end{abstract}

Keywords: Church and Society; conscious; free; philosophy; Secularization; Christianity;

\section{INTRODUCTION}

People are equal before God, says the voice of sociologists, but in reality, cannot be equality. Inequality, superiority or privileges of some people, poverty or subordination of the others are normal, unmodified consequences of ruling the society that is considering a restoration of the right balance in the later life.

The man was born free, having, from the beginning, the power to obey or not God's will. The Creator has given to the compassionate beings that He created the opportunity to move voluntarily and freely, so that they can acquire the true moral values that they can preserve by their own will. But laziness and indifference towards the idea of guarding the good, alienation and neglect to the better is nothing more than heading to worse because, in fact, it is certain that evil is nothing but lack of good. That is what happens if one moves away from right side.

Sociologists, psychologists, researchers in the history of religions, the social policy of states consider work to be the means of man's realization, enrichment in plan, but unfortunately their aspirations do not go beyond the material threshold. They only emphasize the material importance that humanity has given it as a law after falling into sin, after man has forsaken God by disobedience and rebellion upon him. Together with the personal call to happiness, man has the social dimension as an essential component of his nature and his vocation. In fact, all men are called to the same purpose, God Himself; there is a certain resemblance between the communion of divine persons and the fraternity that men have to 
establish between them in truth and in love; love for the neighbor is inseparable from the love for God.

The doctrine of sociology takes into account man's relationship with the society in which he lives, while the Church cannot be indifferent to this relationship and social realities. Christian spirituality is perfectly perceived in the way of life, experience, and work that we encounter in the effort and work of the Savior Jesus Christ. The social morality of Christian life is linked to the mission accomplished by Christ through which spiritual goods flow through the grace of God over the entire world through the church.

\section{THE RELATIONSHIP BETWEEN THE CHURCH, THE WORLD AND SOCIETY}

In Eastern Orthodox Christianity, the relations between the church and the state are established on the basis of the principle of symphony ${ }^{1}$. The exponent of the combined power of the Church and the state was Justinian himself. Novella 154 portrays Justinian above any law: "God has subjugated the kingdom to the king himself, sending him to men as an inbred $l a w "$ ". The church has penetrated into all life sectors. And the political power interfered in all matters of the Church's life. There has also been a harmonization of state and church life. As witness is the administrative territorial division of the Church, from the First Ecumenical Synod (Nicaea, 325$)^{3}$.

The authority of the Church in the life of the city should not be perceived in the absolute sense but nuanced in the direction of the initial authority over its members, which at the same time made up the society. In the present, however, following the changes in the consciousness of the masses due to the French Revolution, the development of the positivist philosophy and the development of science, there is a hiatus between the Church and society. The relationship of the Church with the state has been established by the Savior himself, even during His earthly activity, by the justification of Caesar's request (Matt. 22:17). The answer given by Christ to the Pharisees on the question, "Is it right to give Caesar the imperial tax?" Emphasizes two things: the recognition of state authority, in the case of the imperial state and the reality of non-opposition between religious and civic duties. The autonomy of the Church towards the state, if it means the non-interference of the Church in purely political matters and non-intervention of the state in the internal affairs of the Church, does not mean at the same time the total indifference of the Church to the problems of contemporary society.

Recognizing each other's own identity, the two fundamental institutions, the Church and the State, have complementary purposes that address the same social body. The state is called upon to ensure its physical survival, while the church is called to mediate the becoming of the social body in the flock of God, preparing it for the afterlife. Although he was the keeper of the thesaurus of the teachings of the Savior in the close relationship with the Byzantine political power, Christianity (the religion of the Church) was neither "statized" (and thus secularized) as the liberal science, especially the Protestant, of the nineteenth- and not "paganized to the point of betraying the Evangelical message" ${ }^{4}$.

Divine worship is the very life of the Church and the center of the Orthodox cult is the Divine Liturgy, named by Saint Dionysius the Areopagite the Mystery of the Mysteries,

\footnotetext{
${ }^{1}$ Nicolae Iorga, Istoria vieţii bizantine, Enciclopedică Română, Bucureşti, 1974, p. 21.

2 S.B. Daşkov, Împăraţi bizantini, Enciclopedică, Bucureşti, 1999, p. 73.

3 Jean Meyendorff, Biserica creştină ieri şi azi, Anastasia, Bucureşti, 1996, p. 35.

${ }^{4}$ Ibidem, p. 23.
} 
because it crowns all that has been given through the other ministries and unites the most to every believer and all in the One and infinite God love perfecting communion with God.

The word liturgy comes from the Greek word (leon ergon), through which the Greeks understood every public work or every other thing done for the benefit of the state or the public. The Church intervenes by giving moral appreciation in economic and social matters when this is required by the fundamental rights of the person, the common good or the salvation of souls.

Man as a sociable and social being, is fully accomplished by incorporating himself into the church, by the birth of water and the Spirit (John 3: 5), a new birth given in the "bath of baptism" through "communion with Christ," bringing the Spirit in the human body, sharing the tremendous kindness that irradiates and shines, making it like God. Man has Christ as an opportunity to become God by grace. Through the "bath of baptism we cleanse ourselves from all sin (ancestral or personal), and through the mystery of the Holy Anointing Oil we become partakers of divine gifts, acquiring fellowship in the life of Christ" 5 .

God is the source of absolute love. Love, which is not imposed on humans by itself, does not rises in human beings, but in God, the source of absolute love that attracts those who love Him. Man cannot ascend to God without increasing in the assimilation of his love for men; he cannot complete himself in communion with God without making himself more gifted to others.

Therefore, the communion cannot be done, as in the case of knowledge, only through love. This is the only and viable way of accomplishing the communion, because there is nothing excepting love. "The more people are united by love, the more they are more important, valuable to each other, and in the case of human beings, the more they are united, the more mysterious one is. That's why the mild approach stops the person who loves to roughly treat the loved one. The more they are united, the more they amaze each other and act more and nicer with each other. ${ }^{6}$

Cohesion and social order, the normal development of community life is based on a complicated system of duties, and so what is emphasized always falls on duty, not on rights. Social debt is obedience to the laws of society.

Man is a workman in the eyes of a sociologist, he is a social being, and labor it is the one which emancipates, elevates, rewards and leads him to an ideal state, to an ideal society.

The founders of the liberal thinking of work (the Empire philosophers, Thomas Hobbes and John Locke) in the 19th century struggled to show that the normal natural state of man is an artificial product, slave of the existing social organizations. This opens up the possibility of a new interpretation that reconciles the main freedom of individuals with their current status of subjects: man is born free, but his natural state of freedom has been replaced by an artificial state of multiple addictions. In an effort to articulate this interpretation, original liberalism invented the idea of a natural state of man, supposed to exist before its social state, familiar today to a development through knowledge and labor.

According to this idea, before establishing the social organization, its hierarchical structure, legislation and the state, people were in a state of freedom and equality. If civil society was born on the basis of an initial agreement established between its first members, it must be concluded that the basis of community life is the consent of the people to associate and be led. As John Locke insists, "Political Societies have all begun through a Voluntary

\footnotetext{
${ }^{5}$ Nicolae Cabasila, Despre viaţa în Hristos, transl. by Pr. prof. dr., Ene Branişte şi Pr. prof. dr. T. Bodogae, Edit. Arhiepiscopiei Bucureşti, 1989pg. 149

${ }^{6}$ Pr. Prof. Dr. Dumitru Stăniloae, Studii de teologe dogmatică, Edit. Mitropoliei Olteniei, 1991, p. 205
} 
Union, and through the mutual understanding of the people acting freely in the choice of those who govern them, and in their power to work for the benefit of society"7.

In this initial state, people were guided not by laws issued by a public authority (such an authority did not exist yet), but by the Law of Nature expressed in the voice of Reason. The Nature (not written or written only in the souls of men) says that each individual is destined to pursue his own safety, but also that, given the existing equality, each one must respect the safety of the others, so to refrain from harm or violate their rights.

The idea that people are originally in a natural state in which they are governed only by the laws of nature, an idea of a naturalistic outlook that emphasizes natural things rather than divine decisions, plays a very important role in the liberal conception of labor, because it opens the way to the rejection of the status quo (the state of things in society) defended by traditionalism. As soon as, besides the present social situation (of inequality and dependency), a rival situation arises, the original situation - natural state, equality and independence - gives rise to the possibility to distinguish between the state of affairs (what is) and the state of law (what must be): it can be said that the current social status is not the one in principle; that God did not necessarily want people to live in the state of inequality, subordination, and dependence - moreover, since initially made people equal and free, giving them only the Law of Nature as a guide - it is supposed that he they wanted them to stay that way. Paradoxically, appealing to the naturalist perspective does not put liberalism in conflict with religion, but, on the contrary, it brings the support of divine will to the aid of liberal aspirations. It can now be said that since God created free men, God did not agree that they would be subordinated to an absolute power.

As they evolve, societies face the phenomenon of increasing differentiation or individualization. Common consciousness begins to lose its importance, and so individual consciousness emerges, whereby men differ between themselves. The latter generates an organic solidarity, widespread in modern societies. Certainly, there are no companies operating only on the basis of a single type of solidarity (mechanical or organic), but they tend to one of them.

Durkheim distinguishes social man or ethnic man and the average man. The social man can only be the moral man, while the average man is the ordinary, the common man, the one who is subject of mistakes and faults.

After thousands of years of social existence, they still wonder what the social is. The scientific queries, when they became possible, were limited by the methodological requirements, they did not relate to social existence, they merely assumed it and cut out various "study objects"; some of them have been consecrated as "scientific disciplines" 8 .

The sociology of the $19^{\text {th }}-20^{\text {th }}$ centuries that launches the labor-induced innovation in the Leninist-Marxist conception is accomplished through collectivity, the goods being a common benefit, so everyone is obliged to work for the benefit of the society. In the communist slogans and in the sociology of the times, the state was "a generous being providing bread for everyone, a wedge for all arms, a capital for all the enterprises, credits for all projects, a balm for all the wounds, consolation for all sorrows, solutions for all problems, truths for all minds, fun for all kinds, wine for the elderly.

It used to provide all desires, satisfied all our curiosity, corrected all our errors, amended all our mistakes and absolved everyone the need for providence, caution, judgment,

\footnotetext{
${ }^{7}$ John Locke, The Second Treatise of the Government, Dahrendorf, Ralf, "Modern Social Conflict. Essay on the Freedom Policy", Humanitas," Al. I. Cuza ", CEU Press, 1996, p. 102

${ }^{8}$ Karl R. Popper, Societatea deschisă şi duşmanii ei, Humanitas, Bucureşti,1993, p. 54
} 
intelligence, experience, order, economy, temperance and diligence" ${ }^{9}$. But if the state only divides the citizens that it has already gathered from them and if, as it is obviously, it cannot take a little while in return, it means that the only possible sham that some people might be helped or 'save' would be the one that consists in supporting (financially) some on the basis of funds collected from others.

The conclusion of the exposed concepts leads us to the understanding of the natural moral law which is the foundation of the state and of the social order. The Orthodox Church is not regarded as an organization in the sense of a political or other organization; it is not only the organized life of religious believers, but it is above all the theandric body, the life of God in men, the theandric community, a sacramental community. In this life of communion in the Church, the one who enters is enlightened, is taught by Christ who works in him. The Church, in this sense of communion, deeply overcomes any form of social or other organization. The Church is the mystery of communion with and through the Holy Trinity, the body in which the icon of the Holy Trinity is realized. ${ }^{10}$

The Church's communion character consists not only in the historical and organizational form of the church community, but also in its character of the Lord's secret Body. This character must be taken into account in the answer to the question: what are the ontological and spiritual elements that make it possible for an identity between the Church and communion? At the heart of the idea of communion of the Church in Orthodoxy is its appropriation of the Mysterious Body of the Lord, the clerical church or the Eucharistic Church. These can be considered the premises or sources of the Church's communion idea ${ }^{11}$.

The aspect of communion of the Church is also based on the fact that the man created in the image of God is a subject that manifests an intention for communion. Our entry into the life of triumphal communion is the work of Jesus Christ, which is a center where the intentions of communion have the ultimate intensity, and of the Holy Spirit who is the Spirit of communion. The communion in the Church reflects and validates how to be the work of the ultimate reality of the Holy Trinity. Trinitarian love is the model of love among Christians. God has a personal character and is interpersonal. Man only in communion and in relation to the other is accomplished and knows himself fully and knows the other while loving him at the same time ${ }^{12}$. The Holy Spirit makes every medullar fulfill his own work, but so that it is at the same time a common work, a work of the Church for the Church. It is obvious that each member of the Church, working after his calling, brings his work to the whole Church, as in his turn he shares what all members of the Church do in one place. $\mathrm{He}$ gives in the community, but at the same time takes from this community. This report strengthens the life of communion, the life that is in the Church and the Church. Each of the adults of the Church fulfills in its body its special function that contributes to the good of all. The suffering or good of one has repercussions throughout the body, for the parts are intimately joined together.

When talking about the human community in Christianity, it must first be taken into account the specificity of the Christian faith resulting from the incarnation of Jesus Christ. For the act of the inauguration of Jesus Christ brought with it the dogmatic doctrine that

\footnotetext{
${ }^{9}$ Frédéric Bastiat, "Statul”, in Viaţa românească, anul LXXXIX, nr. 11-12/1994, p. 127.

${ }^{10}$ Pr. Prof. Dumitru Stăniloae, Sinteză ecclesiologică, in Studii Teologice, Year VII (1955), nr. 5-6, p. $272-273$.

${ }^{11}$ Pr. Dr. Dumitru Radu, Indrumări misionare, ediţie colectivă, I.B.M..B.O.R., Bucureşti 1987, p. 380.

${ }^{12}$ Idem, Autoritate şi conciliaritate în practica actuală a Bisericii, convergenţe şi tensiuni, in „Ortodoxia”, Year XLI, Nr. 2, (1989), p. 91.
} 
structured the contents of the human community, but above all the fundamental ontological principle of the visible and spiritual unity of this community.

\section{HUMAN PERSON AND SOCIETY}

Scripture often affirms that God speaks to us through the greatness and beauty of nature: "The heavens say the glory of God, and the making of His hands tells strength. Day tells the day word and night announces science night. There are no words, no words whose voices are not heard. And throughout all the earth their word came out to the word of the world" (Ps. 18, 1-4).

Made up of body and soul, man stands at the midpoint of creation, uniting in himself matter and spirit, forming a connection between the two creations, spiritual and material, visible and invisible. According to St. John Chrysostom, man is composed of two substances - the visible and tangible and another rational, which relate to him both with the sky and with the earth; through his intelligent essence he communicates with the powers that are above him, and by his tangible nature he is bound up with earthly things. "The man, composed of a spiritual soul and a material body, constitutes the unique spiritual-material material psychosomatic in the world, as it was created by the free and creative will of God, a complete and new union of spirit and matter". ${ }^{13}$ This is the combination on which man's splendor and supremacy is based upon all visible beings of which man is distinguished by virtue of his nature and essence, being, according to the Psalmist, a little smaller than the angels, with glory and crowning honor.

The definition given by most of the dictionaries of the "person" ("individual of a human species, considered by all his physical and mental attributes, human being, ins"), but also to the "individual" ("person regarded as a distinct entity from other persons" ) does not cover from the Orthodox perspective any of the fundamental aspects of reality itself ${ }^{14}$.

To understand from the very beginning the distinction between the two terms must be said that unlike a person, a term that refers strictly to the meaning of man and God, the individual is a generic name, by which he can be understood a distinct unit of a species (animal or plant).

Etymologically, the word "individual" derives from the Latin equivalent in which is added the divide of the Greek word "atom" and means "indivisible", which cannot be divided. In the physical domain, the atom is considered a particle of matter that cannot be divided. In the biological field, the individual is a stand-alone unit, separated from other units that cannot be divided without ceasing to be what it is. It has life itself and is manifested in a unitary way. An individual is a quantitative notion, a number among other numbers, having no other characteristic than unity. Individuality presupposes inner unity and qualitative unity, being a qualitative unit. It shows us what distinguishes one person from another, the specific of each one, which belongs only to him and to anyone else. Every individual who comes into the world is unique, has a kind of own, no one else finds them. $\mathrm{He}$ is him. Human nature thus appears not only divided into a multitude of individuals viewed as numerical quantitative units, but also in an infinite variety of individualities, unique qualitative units. Individuality is a native, specific, psycho-physical structure. From the Christian point of view, this structure results from heredity, from the fact that God

\footnotetext{
${ }^{13}$ Protos. Drd. Irineu Pop, Chipul şi asemănarea lui Dumnezeu - dat ontologic şi misiune de realizat, in Glasul Bisericii, anul XLVIII (1989), nr.2-3, p. 79

${ }^{14}$ DEX, Dicţionarul explicativ al limbii române, Institutul de lingvistică „Iorgu Iordan”, 1998, p.782
} 
creates each one with his own seal. Individuality and individuality are, however, terms that apply to animals, and unlike the animal, man is a person.

The term "person" derives from the Latin personality, which translates into a mask covering the face of artists in Antiquity when playing a role, and how the face has only masked man to understand a concrete human face, person-person, as they have translated from Latin. By the name "person" that is attributed only to man it is understood that he is a spiritual being. What makes man a person is not his body, but his spirit, which gives the psycho-physical person the character of person. When we say spirit, we understand a rational and free nature that knows itself and determines itself. But "person" means not only spirit, but also "hypostasis", that is, unity of self-standing, a whole that has its center of existence and life itself. Since "hypostasis" is the common name for all individual, rational or nonrational individual (individual hypostasis), the term "person" is used for rational, "spiritual" hypostases, and for "non-rational" individuals. Every person is a stand-alone unit (individual) and has its unique specificity among the other individuals (individuality) raised to the maximum possible degree.

The dialogue with people began God Himself when He created us creatures endowed with the capacity and duty to engage with Him and with us. Every need to communicate with each other, to talk to each other, to expect answers originates in these gifts that we have received from our Creator. The basis for the dialogue between us is the need for dialogue with Him. We cannot be without others because we cannot be without God.

\begin{abstract}
In order to be able to enter into a full communion with you "I need to communicate certain meanings to you, and if you listen with understanding gain and I have a new understanding of them. I gain in depth, become transparent as a topic by penetrating your subject, or by opening your depths freely. You are my hope and my strength, you are strengthening, and I do, even by the fact that I know your hope and your strength. Your affiliation and mine to a common one makes you, when you cry out for my help, feel that something that belongs to me is in distress, and if I hit you, I shake and fuck myself something more essential than losing a good that is my exclusive ... No one can figure out how much he is worth for another, but he realizes how much another person is worth for him." ${ }^{15}$
\end{abstract}

The dialogue between person and person is under the power of God, as the One who takes care of our people and has made us so important to one another and capable of helping us and enriching our existence one by one. The human word as a means of openness and conscious and free communication is a way of strengthening and developing our nature by realizing its closeness to the infinite divine nature. The Word unites and opens people through communion. It enlarges a person's universe, opening up his or her horizon, partly apart from another person. The Word opens people to others in the light of the infinite love of One in whom there is supreme living and love.

The person is and must be the principle, subject and purpose of all social institutions. Certain societies, such as the family and the civic community, are needed. Other associations are useful both within the political community and internationally, respecting the principle of subsidiarity.

This principle indicates that a higher-level society must not intervene in the internal life of a lower-order society by depriving one of its competencies, but rather to support it if necessary.

The person is, thus, a way of existence that penetrates and makes the entire being personal. It is the subject and the bearer to whom it belongs and in which the being lives as

${ }^{15}$ Pr. Prof. Dumitru Stăniloae, Ascetica şi mistica Bisericii Ortodoxe, I.B.M.B.O.R., Bucureşti, 2002, p. 363. 
such. ${ }^{16}$ Descartes saw that the person is first of all a self-aware existence and affirmed "cogito ergo sum", that is, because I think, thinking that he understood the act of thinking as an act of the person directed at herself, so that act of self-consciousness. ${ }^{17}$

Many centuries before, the patriarch Callistus of Constantinople (14th century) exclaimed: "I love, therefore I am," showing that in communion through love, and not through Descartes' selfish individualism, every person must live its existence. The rhythm and pulse of existence comes from a mutual communication of existence through love. "The person finds sense and happiness only in the endless wealth of meanings and consequently in their infinite mutual experience and communication with other people and with the personal Word, the infinite source of all senses, the lovers of all persons in whom the meanings are embodied." 18

The person, due to the inexhaustible character, proves to be an endless existence. It can never stop from its (spiritual) growth and can never cease in its communion (for others) in receiving and communicating new meanings, meanings and states of mind. He always lives infinitely, but in potency as a target to be achieved. The order and hierarchy of the community, the roles that each mortal must play, the social rank, the moral, legal rules that everybody has to respect are determined by the criterion of competence and labor. All citizens head to a good side: economic, social, moral.

The idea of a state of General Good implies that the state should not confine itself to establishing the rules of 'social play', leaving each participant alone to achieve the performance it is capable of, but to intervene directly to promote the interests of all 'players' (welfare, happiness, equality) according to their wishes, interests or needs.

\section{MISSION OF THE ORTHODOX CHURCH IN THE WORLD}

The mission of the Church is to first preach the gospel about the man as a being created in God's image and likeness, called to be a shareholder of the Kingdom of God. In this framework, the mission of structures in the world is to take care of the human person understood as a member of society. Thus, priority for the mission of the Church is the conversion of man, and for the mission of structures in the world is the transformation of human society. These two roles do not contradict each other, but mutually cooperate in the realization of the Kingdom of Heaven.

The mission of the Church in the world is accomplished through the missionary effort of both the clergy and the laity, for the duty to confess Christ to the world has the Church in its entirety, for it is a reference to the whole community in the world. By nature, the Church is a missionary institution, because it itself originates in the mission of the Son and in the mission of the Holy Spirit, according to the plan of God the Father.

And this plan originates in the "source of love", that is, from the love of God the Father who, being the Beginning, from which the Son is born and from whom the Holy Spirit proceeds through the Son, freely creating us in the infinite and His merciful kindness, and calling us free to share with Him in His life and glory, He gladly poured out His divine goodness and did not cease to overthrow it, so that He, who is the Creator of all, in the latter, "everything in all" (I Co 15, 28), while at the same time realizing His glory and our happiness.

\footnotetext{
${ }^{16}$ Paul Evdokimov, Femeia şi mântuirea lumii, transl. by Gabriela Moldoveanu, Christiana, Bucureşti, 1995, p. 49

${ }^{17}$ Pr. prof. acad. dr. Dumitru Stăniloae, Studii de teologie dogmatică, Mitropoliei Olteniei, 1991, p. 134

${ }^{18}$ Ibidem, p. 69.
} 
The Church - a community of faith lies on the organic unity between the Truth and the Gospel - faith: "And after hearing the word of truth, the gospel of your salvation, you believed in Him, and you were sealed with the Holy Spirit that was promised" (Ephesians 1 , 13). In order to receive Christ from man, faith and repentance are demanded: "Repent and baptize each of you in the name of Jesus Christ for the forgiveness of sins, and receive the gift of the Holy Spirit" (Acts 2:28). Faith is the openness and grace of the divine, it is the means and the condition by which man draws near to God and works through His work in $\operatorname{him}^{19}$.

The mission, in biblical language, is related to the terms of vocation and salvation, and revolves around the verb to send. "Christ and the Church who testify Him through the preaching of the Gospel go beyond every particularity of race and nationality and therefore cannot be considered unknown anywhere and to anyone" ${ }^{20}$.

The mission is a fundamental part of the being of the Church, for the preaching of the gospel of Christ to all nations and the call to "reconciliation through repentance and baptism" ${ }^{21}$. The pastoral mission of Church is not political, economic or social, but first of all the purpose it was set is religious, but without neglecting the political, economic and social implications of the mission, duties that can serve to build and strengthen the community of people according to the divine law.

\section{THE SOCIAL MISSION OF THE CHURCH}

What fundamentally distinguishes Christianity from other religions is that the notion of "neighbor" has a universal character, regardless nationality, social status, sex or religious belief. In this regard, the Apostle Paul tells us: "there is not here Jew or Greek, there is not here servant or freeman, there is not here male and female, for all you are one in Christ Jesus." (Gal. 3:28). "Learning by deeds is far more accurate and worthy of belief than word teaching. For one like this one, even silent and disobeying a word, can educate some by seeing others by hearing" ${ }^{22}$.

Every human community needs a legitimate authority to ensure order and contribute to the realization of the common good. This authority finds its foundation in human nature because it corresponds to the order established by God.

The authority is legitimately exercised when acting for the common good and to obtain it using morally permissible means. That is why political regimes must be determined by the free decision of citizens and must respect the principle of the "rule of law" in which the law is sovereign, and not the arbitrary will of the people. Unfair laws and measures contrary to moral order do not bind to consciousness.

The Church has always been concerned with the material but also the spiritual needs of the believers, viewed in the light of the religious objective it pursues. Commonly understood is the set of conditions of social life that allow groups and individuals to attain perfection.

\footnotetext{
${ }^{19}$ Pr. prof. dr. Dumitru Radu, Păstrarea dreptei credinţe condiţie a dobândirii mântuirii, in BOR, No. 1-2, (1983), p. 51

${ }^{20}$ Pr. Dr. Gheorghe Petraru, Dialogul interreligios in perspectiva teologiei Bisericii Ortodoxe in: Dialog Teologic, Presa Buna, Iasi, 1999, p.11

${ }^{21}$ Pr. Prof. Dr. Ioan Bria, , Iisus Hristos, Enciclopedică, Bucureşti ,1992, p. 254

${ }^{22}$ Gh. D. Metallinos, Parohia - Hristos în mijlocul nostru, Deisis, Sibiu, 2004, p.75
} 
Common good means: respecting and promoting the fundamental rights of the person; the development of the spiritual and temporal properties of people and society; peace and security of all.

Human communities have always included individuals who, due to genetic, material or social causes, have been unable to satisfy their needs by their own means. Along with the many means the Church has to call people to a dignified and honest life, from the earliest times, various moral and material support systems of those found in impasse, orphaned, sick, the poor, etc., who at one point need social protection so that they can be replayed to society shortly. The oldest religious societies were widows, virgins and deacons who were living to help others. The main institutions of social assistance organized by the Old Church supported the oldest families, the poor families, the orphaned or abandoned children and the elderly, by providing them with care, schooling and the appropriation of the church worship in order to socially reintegrate them.

Each person, depending on their place and role, is involved in promoting the common good, respecting the right laws and engaging in areas that require personal responsibility, such as taking care of their own family and engaging in their own work. Citizens should, as far as possible, take an active part in public life.

Society ensures social justice when respecting the dignity and rights of the individual, the very purpose of the same society. Society also pursues social justice, which is related to the common good and the exercise of authority, when it realizes the conditions that allow associations and individuals to obtain what they are entitled to.

There are unjust, economic and social inequalities that hit millions of human beings; they are in contradiction with the Gospel, contrary to righteousness, dignity, peace. But there are also differences between people caused by different factors that come into God's plan. In fact, he wants everyone to receive from others what he needs, and those who have special talents to share with others. These differences encourage and often force people to be magnificent, benevolent and share and encourage cultures to enrich each other.

Solidarity, which derives from the human and Christian fraternity, is expressed first of all in the fair distribution of goods, in the right pay for work and in the commitment to a more just social order. The virtue of solidarity also realizes the sharing of spiritual things of faith, more important than material things.

In Christianity, the love of the neighbor has a new reason: the love of God. The Savior shows that there is an indissoluble connection between God's love and the love of one's neighbor (Matthew 22: 37-39). Love of the neighbor appears as a manifestation of love for God and as an obvious proof of it. In this sense, St. John the Evangelist says, "If anyone says: I love God, and my brother hates him, he is a liar; for he who does not love his brother, whom he has seen, God whom he has not seen, cannot love Him. And this commandment we have from Him: who loves God to love his brother "(1 John 4: 20-21) ${ }^{23}$. „Theocentrism is the fundamental characteristic of Christian love, God being love itself (1 John 4: 8), it is not isolated from people, but unanswered to spread their love over them, thus making people love Him. " 24

Considering the great difficulties faced by today's Romanian society, the role of the Church is even more significant. The fulfillment of the Church's social mission to the world must involve the whole ecclesial community. In its involvement in social matters, dialogue

${ }^{23}$ Pr. Prof. Dumitru Stăniloae, „Să nu ucizi”, in: Biserica Ortodoxă Română, LXXXII, 1964, No. 34, pp. 203-205.

${ }^{24}$ Dimitrie Belu, Despre iubire, Timişoara, 1945, p. 50. 
with civil society and other Churches is directly dependent on the quality of the formation of the consciences of believers, given the specific mission to the world and its realities. In this regard, the bishops need to reflect together and see if it is not the case, along with the biblical catechesis, along with liturgical catechesis, to be a social catechetical program. Gaudium et spes is the basic platform of such a social catechesis.

"Not only the communion and the unity of the members of each local community, but also the inter-communitarian, that the term society represents the Church's expression of the spiritual and essential organization of the life of its members and of the divine structure of its mission in the world.

In conclusion, through social concern as part of the mission of the primary Church, the communal consciousness, i.e. the ecclesial membership of the Church, is expressed, based on the equality and unity of all believers in Christ. ${ }^{26}$

\section{CONCLUSIONS}

No matter how rationally evolved human society is, it does not manifest itself united because the feeling of unifying love is limited and isolated in family groups. The good seed of Christians, fraternity and love, is undoubtedly the common belief of the teaching of Christ that the true the Holy Gospels is today a model of the human being. The harmony and communion of Christian life is given by the moral virtues fulfilled by each member of the church in part with humility and obedience as the Savior says: " Greater love has no one than this: to lay down one's life for one's friends." (John 15,13). You won't be able to say, 'Here it is!' or 'It's over there!' For the Kingdom of God is already among you." (Luke 17:21) so God blesses those whose hearts are pure, for they will see God (Matthew 5, 5-9), thereby becoming the ones spreading the peace.

The Church, as the extension of the Body of Christ in the whole world, does not lead to it as a social reality, making itself felt in the world through duties and both the Church and the world are creations of God. The world is for the Church, the environment in which lives, the environment in which it accomplishes the commandments received from its Founder. The authority of the Church in the life of the city should not be perceived in the absolute sense but nuanced in the direction of the initial authority over its members, which at the same time constituted society.

But the church can and must be engaged in politics in ways and methods specific to its mission. Its role in the moral guidance is permanent, not limited to moral norms, and covering all spheres of social life, which politics is part of. The Church has the duty of creating the desire to clean the political act, the desire to cleanse it, not only on the surface, but in the profound reformation of the reorientation of priorities, in the minds and hearts, because regardless of the time preached, regardless of the historical-political conditions, the Church's discourse was delivered in aiming same direction - the love of the country, of the work of creating values, image of God.

\footnotetext{
${ }^{25}$ Christos Volugaris, Teologia istorică a Bisericii, Sf. Gheorghe-Vechi, Bucureşti, 2001, p. 334.

${ }^{26}$ Pr. Dr. Constantin Preda, Credinţa şi viata Bisericii Primare. O analiză a Faptelor Apostolilor, in: Studii Teologice, No. 1-2, 2002, p. 78.
} 


\section{BIBLIOGRAPHY:}

[1] Bastiat Frédéric, Statul, in Viaţa românească, anul LXXXIX, nr. 11-12/1994,

[2] Belu Dimitrie, Despre iubire, Timişoara, 1945 ,

[3] Bria Pr. Prof. Dr. Ioan, Iisus Hristos, Ed. Enciclopedică, Bucureşti ,1992,

[4] Cabasila Nicolae, Despre viaţa în Hristos, ed. traducere Pr. Prof. Dr, Ene Branişte, şi Pr. Prof. Dr T. Bodogae, Edit. Arhiepiscopiei Bucureşti, 1989

[5] Daşkov S.B., Împăraţi bizantini, Editura Enciclopedică, Bucureşti, 1999

[6] DEX, Dicţionarul explicativ al limbii române, Institutul de lingvistică „Iorgu Iordan”, 1998, p.782

[7] Evdokimov Paul, Femeia şi mântuirea lumii, trad.de Gabriela Moldoveanu, Editura Christiana, Bucureşti, 1995,

[8] Iorga Nicolae, Istoria vieţii bizantine, Editura enciclopedică română, Bucureşti, 1974,

[9] Locke John, The Second Treatise of the Government, Dahrendorf, Ralf, "Modern Social Conflict. Essay on the Freedom Policy ", Humanitas," Al. I. Cuza ", CEU Press, 1996,

[10] Metallinos Gh. D., Parohia - Hristos in mijlocul nostru, Ed. Deisis, Sibiu, 2004,

[11] Meyendorff Jean, Biserica creștină ieri şi azi, Editura Anastasia, Bucureşti, 1996,

[12] Petraru Pr. Dr. Gheorghe, Dialogul interreligios in perspectiva teologiei Bisericii Ortodoxe in Dialog Teologic, Ed. Presa Buna, Iasi, 1999,

[13] Pop Irineu Protos. Drd., Chipul şi asemănarea lui Dumnezeu-dat ontologic şi misiune de realizat, în G.B.,anul XLVIII (1989), nr.2-3,

[14] Popper Karl R., Societatea deschisă şi duşmanii ei, Editura Humanitas, Bucureşti,1993,

[15] Pr. Prof. Dumitru Stăniloaie, Sinteză ecclesiologică, in Studii Teologice, an VII, nr. 5-6, (1955)

[16] Preda Pr. Dr. Constantin, Credinţa şi viata Bisericii primare. O analiză a Faptelor Apostolilor, in Studii Teologice, nr.1-2, 2002,

[17] Radu Pr. Dr. Dumitru, Autoritate şi conciliaritate în practica actuală a Bisericii, convergenţe şi tensiuni, in Ortodoxia, An. XLI, Nr. 2, (1989),

[18] Radu Pr. Dr. Dumitru, Îndrumări misionare, ediţie colectivă, edit. I.B.M, Bucureşti 1987,

[19]Radu Pr. Dr. Dumitru, Păstrarea dreptei credinţe condiţie a dobândirii mântuirii, in Biserica Ortodoxa Romană, Nr. 1-2, (1983),

[20] Staniloae Pr. Prof. Dumitru, Sa nu ucizi, in Biserica Ortodoxa Romana,LXXXII, 1964, nr. 3-4,

[21] Stăniloae Pr. Prof. Acad. Dr. Dumitru, Studii de teologie dogmatică, Editura Mitropoliei Olteniei, 1991,

[22] Stăniloaie Pr. Prof. Dumitru, Ascetica şi mistica Bisericii Ortodoxe, Edit. I.B.M., Bucureşti, 2002,

[23] Volugaris Christos, Teologia istorică a Bisericii, Ed. Sf. Gheorghe Vechi, București, 2001, 